\title{
Ugly, messy and nasty debate surrounds circumcision
}

$\mathrm{T}$

he comments section following an online article about circumcision can be a nasty, nasty place. Those in favour of the procedure often ridicule those who oppose it, calling them little more than cultish foreskin worshippers. The anti-circumcision crowd also tends to be blunt, labelling fans of defrocked phalluses as supporters of genital mutilation.

And this at-times-uncivil debate shows no signs of abating. More people are promoting circumcision for health reasons, buoyed by influential clinical research that suggests circumcision can reduce HIV transmission. At the same time, groups opposed to circumcision are popping up all over the place, some attempting to ban the practice for violating basic human rights, others intent on exposing flaws in pro-circumcision research.

"I have never seen anything in medical literature as bad as circumcision literature. A lot of it stands out to me as bullshit," says Dr. George Denniston, founder of Doctors Opposing Circumcision, based in Seattle, Washington. "Advocates for circumcision use medical literature to promote their cause and don't give a damn if it's true or not. I don't think this is controversial at all. It's cut and dry. There is just no way it should be done. Circumcision violates the first rule for doctors: to do no harm."

The other side of the argument is that anti-circumcision groups are disparaging solid clinical evidence of the health benefits of circumcision while bombarding the Internet, newspapers and anyone else who will listen with misinformation. These people are a "very vocal minority of opponents, who are frustrated to find that the science does not support their rhetoric," Brian Morris, a long-time advocate for circumcision and a professor of molecular medical sciences at the University of Sydney, Australia, writes in an email.

On his website, Morris says some people have suggested that anti-circumcision groups "should really be

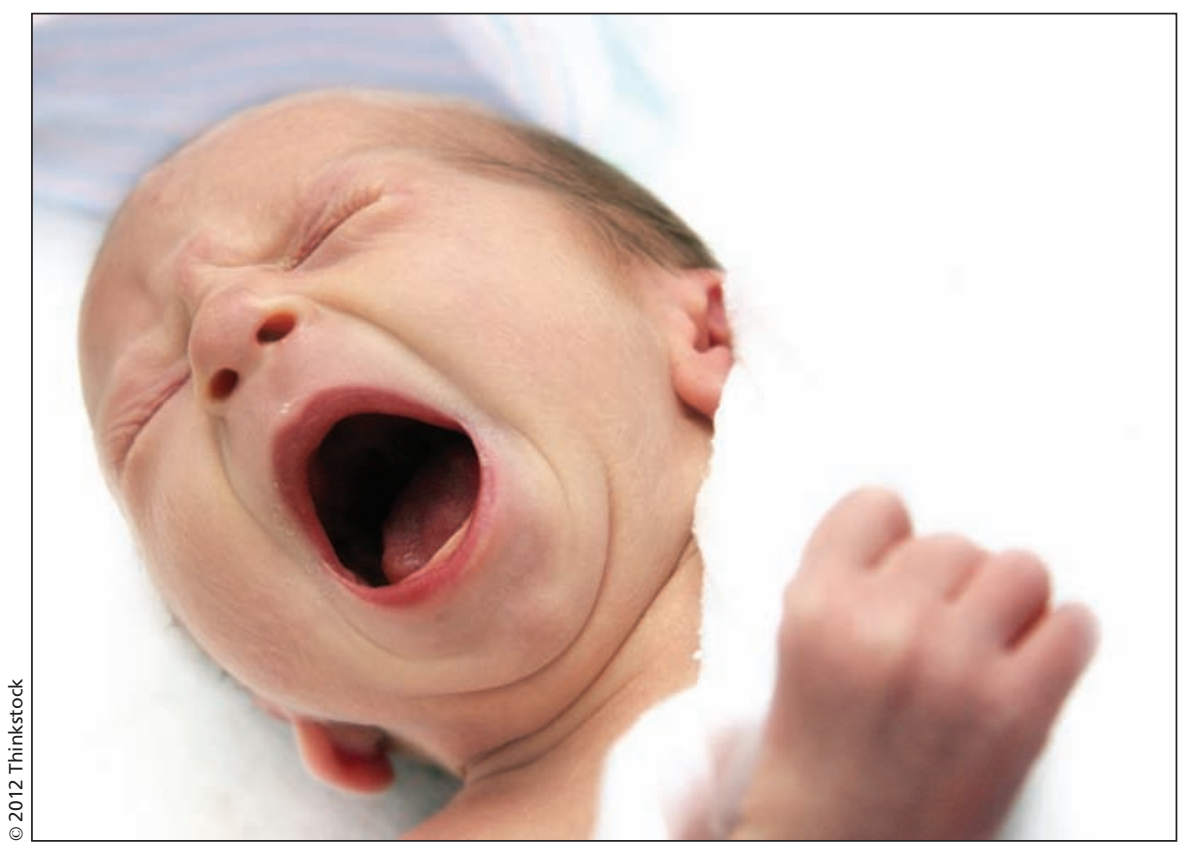

According to some opponents of infant circumcision, doctors who perform the procedure violate a basic tenet of medicine: to do no harm.

regarded as a cult devoted to worship of the foreskin" (www.circinfo.net/anti _circumcision_lobby_groups.html). The arguments made by such groups come from a "moral absolutionist" position, he suggests, and thus prohibit compromise. "This is not to say that all claims made by anti-circ groups are invalid," Morris wrote on his website. "Rather, given the cult-like devotion of anti-circ groups to their cause, any claims made by anti-circ groups should be thoroughly verified by independently examining the empirical research findings."

The centre of the battle over circumcision lies in the United States, the only Western nation in which the vast majority of adult men, around $80 \%$, are circumcised (though rates of infant circumcision are falling). To combat what they see as culturally acceptable mutilation, many American opponents of infant circumcision have in recent years formed groups to spread their message.

In addition to Denniston's group, there is the National Organization to Halt the Abuse and Routine Mutilation of Males (NOHARMM), the National Organization of Circumcision Information Resources Centers (NOCIRC), Intact America and the Stop Infant Circumcision Society.

One organization, Male Genital Mutilation Bill, is lobbying for a national act to prohibit infant circumcision in the United States. Others have pushed for bans in various states or at the municipal level. For example, a ban was recently proposed in San Francisco, California, for the city's November 2011 ballot, though it was later struck down by a judge as an attempt to regulate a medical procedure.

There is even a group, the National Organization of Restoring Men (NORM), that helps circumcised men create new foreskins through skinstretching techniques. "The people on the pro-circ side just seem to ignore the real structure and function of the foreskin," says Wayne Griffiths of San Francisco, California, one of NORM's cofounders and its executive director. "The thing that doctors learn in school is that the foreskin is the redundant skin in front of the glans that is cut off during 
circumcision. But that is up to 100000 nerve endings that they are cutting off."

The rise of the anti-circumcision movement has also given rise to a new nomenclature. The movement itself, for instance, is sometimes called "intactivisim" and adherents have referred to themselves as "intactivists" who stand for "genital integrity." Another term that sometimes surfaces is "circumfetishism," which refers to sexual gratification derived from observing or performing the act of circumcision. A small number of the more radical opponents of circumcision have even accused some doctors who perform the procedure as being "circumfetishists," but such accusations appear to be baseless, though they do indicate just how nasty the debate can get.

One factor that may lead men to abhor circumcision, even if they aren't aware of it, is the high value they place on their genitals, which some view as the essence of their manhood, urologist Dr. Jack Lapides and colleagues wrote in a paper on the topic ( $J$ Urol 1973;110:7980). It should come as no surprise, then, that some men are afraid of damaging those prized assets and don't want a blade anywhere near them. The paper also notes that a backlash against circumcision was inevitable considering the long history of misleading health claims made by proponents of the procedure.

At various times over the past 140 years, ridding the penis of its foreskin has been touted as a cure for paralysis, restless sleep and bad digestion, among other ailments. In the 19th century, circumcision was viewed as a remedy for masturbation, a practice some believed led to mental illness, convulsions and blindness. Unfortunately, some circumcision advocates claim, the backlash against these unscientific claims has been excessive and has precluded some people from objectively evaluating modern data that suggest there are legitimate health benefits to circumcision, such as a reduction of penile cancer and HIV transmission. "The analogy of throwing out the baby with the bath water has never been more applicable," Lapides states.

But empirical data, sound or not, are irrelevant to some opponents of infant circumcision. They view it as a human rights issue, similar to female genital mutilation, a practice that is universally reviled and condemned. To alter a person's body without their consent is wrong, they claim, even if there are potential health benefits. "There may be a case that male circumcision reduces HIV risk in sexually active adults, but the decision about whether to have this procedure should be left until the person is old enough to make his own informed healthcare choices," emergency physician Dr. Geoff Hinchley wrote in an editorial (BMJ 335:1180 doi: 10.1136 /bmj.39406.520498.AD).

Opponents of infant circumcision tend to steer away, however, from tackling religious arguments in favour of the procedure. Millions of male infants around the world are circumcised if born into the Jewish or Muslim faiths, which view it as integral to their religions. People who come out against this practice are often accused of attacking freedom of religion or, even worse, of being anti-Muslim and anti-Semitic. The popular actor Russell Crowe, for example, was recently accused of making anti-Semitic comments on Twitter in a rant against circumcision.

"Circumcision is barbaric and stupid. Who are you to correct nature?" Crowe wrote. "Is it real that God requires a donation of foreskin? Babies are perfect." — Roger Collier, CMAJ

CMAJ 2012. DOI:10.1503/cmaj.109-4017

Editor's note: Fifth of a six-part series:

Part I: Circumcision indecision: the ongoing saga of the world's most popular surgery

(www.cmaj.ca/lookup/doi/10.1503

/cmaj.109-4021).

Part II: Vital or vestigial? The foreskin has its fans and foes (www.cmaj.ca/lookup/doi/10.1503 /cmaj.109-4014).

Part III: Whole again: the practice of foreskin restoration

(www.cmaj.ca/lookup/doi/10.1503

/cmaj.109-4009).

Part IV: Late cuts: an international look at adult circumcision (www.cmaj.ca/lookup/doi/10.1503 /cmaj.109-4013). 